\section{Ks. Grzegorz Rafiński}

Gdańskie Seminarium Duchowne

g.rafi@wp.pl

DOI: http://dx.doi.org/10.12775/BPTh.2016.028

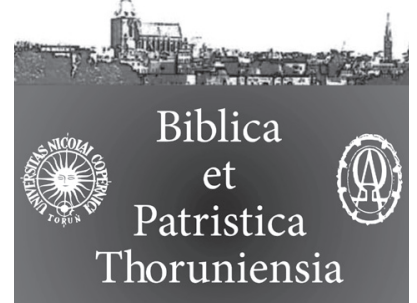

9 (2016) 3: 183-198

ISSN (print) 1689-5150

ISSN (online) 2450-7059

\title{
Ideał tolerancji w świetle przesłanek zawartych w Listach św. Pawła (część druga: reguły wykonawcze) ${ }^{1}$
}

\section{The ideal of tolerance in light of the premises contained in the Letters of St. Paul (Part Two: implementing rules)}

Streszczenie. Artykuł niniejszy stanowi kontynuację artykułu opublikowanego w poprzednim numerze „Biblica et Patristica Thoruniensia”, w którym zostały omówione zagadnienia wstępne, włącznie z analizą 1 Kor 8-10, która wykazała, że tolerancja jest podporządkowana miłości - nie jest wartością absolutną, autonomiczną. W artykule niniejszym zostały wskazane reguły wykonawcze dotyczące tolerancji i nietolerancji. Chrześcijanie powinni być tolerancyjni wobec „tych, którzy są na zewnątrz [Kościoła]” i nietolerancyjni wobec zła popełnianego przez „tych, którzy są wewnątrz [Kościoła]” (1 Kor 5,12-13), w granicach wyznaczonych przez autorytet apostolski (1 Kor 5,3-11). Zakładając, że tolerancja w Kościele jest pochodną miłości, a jej granice wyznacza autorytet apostolski, pozostaje niemała sfera decyzji w życiu chrześcijanina, w której powinien on okazywać tolerancję wobec błędów popełnianych przez współ-chrześcijan. Św. Paweł wymienia w Rz 14 trzy okoliczności, w których zaleca postawę tolerancji (zob. Rz 14,15.19.22). W Rz 12,1-2 i w 1 Kor 6,1-11 znajduje się odpowiedź na pytanie, w jaki sposób chrześcijanie mogą „przekładać” Ewangelię o tolerancji na realia życiowe. Powinni kierować się rozumem (oświeconym przez Ducha Świętego), a ponadto, ich postawa powinna być realizacją „wyższej sprawiedliwości” opartej na Ewangelii, która różni się od mądrości świata.

Abstract. This article is a continuation of thepaper published in the previous issue of "Biblica et Patristica Thoruniensia" that discussed the preliminary study, including the analysis of 1 Cor $8-10$, which showed that tolerance is subordinated to love and, as such, it does notconstitute any absolute or autonomous value.In this paper, various

1 Artykuł niniejszy stanowi kontynuację artykułu opublikowanego w pierwszym numerze „Biblica et Patristica Thoruniensia” z 2016 r., w którym zostały omówione zagadnienia wstępne (zob. G. Rafiński, Ideał tolerancji $w$ świetle przesłanek zawartych $w$ Listach św. Pawła (część pierwsza: zagadnienia wstępne), BePTh 9(2016)1, s. 83-95). 
implementing rules related to both tolerance and intolerance were identified. Christians should be tolerant of "outsiders" and intolerant of evil committed by "those inside [the Church]" (1 Cor 5:12-13), within the limits set by the apostolic authority (1 Cor 5:3-11). Assuming that tolerance in the Church is a consequence of love, and that its limits are set by the apostolic authority, it may be concluded that there is a significant sphere for decisions in the life of every Christian in which they should show tolerance for mistakes made by other Christians. In Rom 14, St. Paul mentions three different sets of circumstances under which the attitude of tolerance is recommended (see: Rom 14:15.19.22). In Rom 12:1-2 and 1 Cor 6:1-11, there is an answer to the question about how Christians can "translate" the Gospel of tolerance to everyday reality. They should be guided by reason (enlightened by the Holy Spirit), and their attitude should constitute the realization of "higher justice" based on the Gospel, which is different from the wisdom of this world.

Słowa kluczowe: tolerancja; nietolerancja; sądzić.

Keywords: tolerance; intolerance; to judge.

\section{Wstęp: problem tolerancji w środowisku św. Pawła}

T Tozniowie Jezusa mieli problem z podejściem do tych, którzy nie przyjęli Ewangelii. Świadczy o tym przypowieść Jezusa opisana w Mt 13,24-30, za pomocą której Jezus naprowadzał uczniów na właściwe rozumienie ich relacji ze światem. W przypowieści tej nieprzyjaciel „człowieka, który posiał dobre nasienie na swojej roli” (Mt 13,24) przyszedł i „nasiał chwastu między pszenicę” (Mt 13,25). Słudzy gospodarza pytali, czy mogą pójść i zebrać chwast (Mt 13,28). Nie uzyskali zgody gospodarza, który polecił im: „Pozwólcie obojgu róść aż do żniwa; a w czasie żniwa powiem żeńcom: Zbierzcie najpierw chwast i powiążcie go w snopki na spalenie; pszenicę zaś zwieźcie do mego spichlerza” (Mt 13,30-31).

W tle przypowieści dostrzec można polemikę z modelem nietolerancji wobec tych, którzy nie przyjęli Ewangelii, który ma swe korzenie w Starym Testamencie.W Starym Testamencie, w kontekście wojny o Ziemię Obiecaną, opisany jest model współistnienia tolerancji i nietolerancji, według którego członkowie ludu Bożego powinni zjednoczyć się w walce przeciwko wrogom, którymi są ościenne narody. Ucieleśnieniem tego rodzaju postawy jest tzw. prawo „cheremu”, którego istotę oddaje między Kpł 27,29: „Żaden człowiek, który jest poświęcony dla Pana jako «cherem», nie może być wykupiony. Musi on 
być zabity" (por. Pwt 7,1-2; Joz 11,14-15)2. Prawo, które zakłada nietolerancję wobec „obcych”, okazuje się być niewystarczające w sytuacji „normalnego życia”. Nie tylko w NT, ale już w czasach ST znajdujemy intuicje, które pokazują konieczność odejścia od tego modelu:

a) ST zna pogan, którzy są uznani za postacie pozytywne, np. Cyrus Perski (zob. Iz 44,24.27; 45,1-4). Strefa „dobra” obejmuje też „obcych”, z tym, że powodem jest ciągle ich służebność wobec „swoich”.

b) Prorocy ST, począwszy od Ozeasza i Amosa (VIII w. przed Chr.), krytykują zło obecne w instytucjach władzy i kultu. Strefa „zła” jest obecna więc też wśród „swoich”. Pojawiają się też u proroków wątki uniwersalistyczne.

Na przełomie ST i NT skrajną postać tego modelu obserwujemy w odłamie judaizmu z Qumran nad Morzem Martwym. Wedle świętych ksiąg qumrańskich świat dzieli się na „synów światłości” i „synów ciemności”, przy czym ci pierwsi są reprezentowani tylko przez qumrańczyków. Od „synów ciemności” trzeba oddzielić się w oczekiwaniu na Bożą interwencję, która odmieni świat. Takie było uzasadnienie powstania osady qumrańskiej na pustyni. Qumrańczycy opisywali swe życie w kategoriach wojennych (zob. dokument zwany „Regułą wojny”). „Obcy” przynależy do obozu wrogiego, a staje się „swoim” tylko poprzez przystąpienie do wspólnoty. Zauważmy, że dla podtrzymania takiego modelu konieczne było wytworzenie atmosfery wojny (NB. Znają ten mechanizm do dziś totalitarni władcy).

Podobnie jak w ST, także w tekstach z Qumran pojawiają się z czasem dowody na to, że model ten nie wytrzymał we wspólnocie konfrontacji z życiem. Późniejsze warstwy pism qumrańskich zawierają pogląd, że obok „ducha dobrego” również „duch przewrotności” jest obecny we wspólnocie ${ }^{3}$.

\section{Prymat miłości a zasada nietolerancji wobec zła w Kościele i tolerancji wobec nie-chrześcijan (1 Kor 5,1-13)}

Św. Pawełdoskonale wpisuje się w nauczanie Jezusa (por. Mt 13,24-30), dając wyraz swojemu rozumieniu Ewangelii.Pogląd św. Pawła na tolerancję i nietolerancję zawarty w 1 Kor 5,1-13 jest przeciwstawny wobec schematu postępowania, który św. Paweł znał z Biblii (ze ST) i który istniał np. w Qumran, co, w uproszczeniu, obrazują poniższe schematy.

2 Por. G. von Rad, Teologia Starego Testamentu, s. 186-187.

31 QS 3,13-4,26 (por. G. Rafiński, Z problematyki genezy, s. 465-476). 
Mentalność wynikającą z prawa „cheremu” ilustruje następujący schemat:

„OBCE NARODY”

NIETOLERANCJA

„OBCE NARODY”
"LUD BOŻY”

TOLERANCJA

„LUD BOŻY”
„OBCE NARODY”

NIETOLERANCJA

„OBCE NARODY”

Św. Paweł zaleca w 1 Kor 5,1-13 sposób postępowania dokładnie odwrotny, gdy chodzi o relacje Kościoła ze światem:

„Ci, którzy są na zewnątrz”

TOLERANCJA

„Ci, którzy są na zewnątrz"
„Ci, którzy są wewnątrz" NIETOLERANCJA

„Ci, którzy są wewnątrz"
„Ci, którzy są na zewnątrz" TOLERANCJA „Ci, którzy są na zewnątrz"

\subsection{Teza wynikająca z 1 Kor 5,1-13}

Św. Paweł koryguje błędną postawę Koryntian, podając trzy reguły. Postawa tolerancji musi mieścić się $\mathrm{w}$ granicach wyznaczonych przez autorytet apostolski (1 Kor 5,3-11) ${ }^{4}$. Logika perykopy zawartej w 1 Kor 5,1-13 zmierza ponadto do wniosku zawartego w dwóch ostatnich wierszach tej perykopy: „Jakże bowiem mogę sądzić tych, którzy są na zewnątrz? Czyż i wy nie sądzicie tych, którzy są wewnątrz? Tych, którzy są na zewnątrz, osądzi Bóg. Usuńcie złego spośród was samych" (1 Kor 5, 12-13). Z wierszy tych wynika, że chrześcijanie powinni być tolerancyjni wobec „tych, którzy są na zewnątrz [Kościoła]” i nietolerancyjni wobec zła popełnianego przez „tych, którzy są wewnątrz [Kościoła]”.

\subsection{Problemy chrześcijan z Koryntu wynikające $z$ ich błędnego rozumie- nia Ewangelii}

W sekcji listu zawartej w 1 Kor 1,10-6,20 św. Paweł nawiązuje do wieści, które dotarły do niego z Koryntu. W 1 Kor 5-6 reaguje na przejawy korynckiej gnozy, która owocowała rozluźnieniem moralnym. Właśnie rozluźnienie moralne było tłem szeregu błędów: zbytniej tolerancji wobec zła (1 Kor 5,1-13), kłótni rozstrzyganych w oparciu o sprawiedliwość świata, a nie przez odniesienie do „wyższej sprawiedliwości” opartej na Ewangelii (1 Kor 6,1-11) oraz pogardzania ciałem (1 Kor 6,12-20).

Koryntianie błędnie interpretowali Ewangelię głoszoną przez św. Pawła, absolutyzując tolerancję wobec zła (bo przecież „wszystko mi wolno”; 1 Kor 6,12).

4 Św. Paweł pozostawia przestrzeń dla indywidualnych decyzji chrześcijan, do czego nawiążemy w zakończeniu artykułu, przy analizie Rz 12,1-2. 
U źródeł ich błędu leżała duma płynącą z posiadanej „mądrości”, przekonanie o szczególnym zaawansowaniu w rozumieniu Ewangelii. Korynccy chrześcijanie byli tak dalece tolerancyjni, że nie zareagowali na grzech popełniony przez jednego z członków ich wspólnoty, określony przez św. Pawła jako „rozpusta”

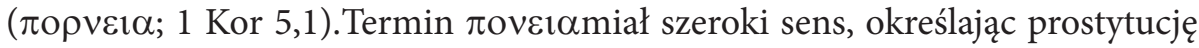
i wszelkie niedozwolone skrajności seksualne. Czyn, do którego odnosi się św. Paweł w 1 Kor 5,1, polegał na współżyciu mężczyzny (chrześcijanina) z macochą. Nie wiemy, czy fakt ten miał miejsce przed, czy po śmierci ojca mężczyzny. Kobieta była poganką (dlatego św. Paweł nie ocenia jej postępowania).

\subsection{Korekta postawy Koryntian dokonana przez św. Pawła}

Zakaz współżycia ojca i syna $\mathrm{z}$ tą samą kobietą istniał zarówno w środowisku pogańskim, jak i żydowskim ${ }^{5}$. Jest też oczywisty dla św. Pawła (zob. 1 Kor 5,2), któremu „casus” związany z jednostką służy do ukazania szerszego problemu dotyczącego Kościoła. Kościół koryncki, który okazał się być niezdolnym do wyciągnięcia właściwych wniosków z Ewangelii głoszonej przez Pawła, powinien na nowo przemyśleć, jak daleko może sięgać „oświecona” tolerancja. Szczególnego dramatyzmu nadaje sytuacji opisywanej w 1 Kor 5,1-13 następna perykopa (1 Kor 6,1-11), w której św. Paweł wyrzuca Koryntianom, że prześcigali się $\mathrm{w}$ sądzeniu siebie nawzajem przed sądami pogańskimi, zamiast poddawać się osądowi przedstawicieli Kościoła, a także sekcja wcześniejsza (1 Kor 1,10-4,21), z której wynika, że Koryntianie krytycznie osądzali samego Pawła (zob. 1 Kor 4,3-5). Z taką postawą kontrastuje tolerancja wobec publicznego grzesznika opisana w 1 Kor 5,1-13. Św. Paweł podaje trzy reguły, których przyjęcie miało uporządkować sytuację w Kościele korynckim.

\subsubsection{Tolerancja musi mieścić się w granicach wyznaczonych przez autorytet apostolski}

Św. Paweł chce skłonić Koryntian do powrotu do właściwego rozumienia Ewangelii, posługując się argumentem $\mathrm{z}$ autorytetu (1 Kor 5,3-5). W tym przypadku odwołuje się do swego autorytetu apostolskiego. Ostro ocenia postawę Koryntian („Wcale nie macie się czym chlubić!”; 1 Kor 5,6). W przeciwieństwie do tych, którzy nie żądali usunięcia ze wspólnoty sprawcy przestępstwa (1 Kor 5,2), Paweł - nieobecny wprawdzie ciałem, ale obecny duchem - już go potę-

5 Zob. Kpł 18,7-8; Am 2,7b; Józef Flawiusz, Ant. 3.274; Filon, Spec. Leg. 3,12-21; mSanh. 7.4; bSanh.54a; TestRub.; Gaius, Instiyutiones 1.63; Cyceron, Cluent. 6 (por. G.G. Fee, The First Epistle, s. 200-201). 
pił (1 Kor 5,3). Następnie Apostoł wzywa Koryntian do zebrania się „w imię Pana naszego Jezusa” i do podjęcia takiej samej decyzji („,w łączności z duchem moim i z mocą Pana naszego Jezusa"; 1 Kor 5,4).

Św. Paweł opisuje decyzję, której żąda od Koryntian, jako „wydanie takiego szatanowi na zatracenie ciała, lecz ku ratunkowi jego ducha w dzień Pana Jezusa” (1 Kor 5,5). „Wydanie szatanowi” nie wynika z chęci potępienia grzesznika, gdyż ma na celu „zatracenie ciała” (tzn. zniszczenie jego grzesznych pożądliwości) i „ratunek jego ducha” („duch” nie oznacza tu „części” człowieka, ale określa całego człowieka żyjącego w bliskości z Bogiem). Upokorzenie grzesznika ma na celu nakłonienie go do pokuty, ku jego ratunkowi. Św. Paweł porównuje ten akt do zwyczaju żydowskiego związanego z obchodami Paschy, a mianowicie do wyrzucania przed tym świętem $\mathrm{z}$ domu starego kwasu (1 Kor 5,6-8; por. Wj 12,15n; 13,7). Przypomina też o tym, że we wcześniejszym liście (niezachowanym do naszych czasów) nakazywał Koryntianom, aby nie obcowali z rozpustnikami (1 Kor 5,9), „Z takim, który nazywając się bratem, w rzeczywistości jest rozpustnikiem, chciwcem, bałwochwalcą, oszczercą, pijakiem lub zdziercą" (1 Kor 5,11). Apostoł obejmuje takich chrześcijan czymś w rodzaju ekskomuniki („Z takim nawet nie siadajcie wspólnie do posiłku”; 1 Kor 5,11). Osąd tak postępujących, którzy należą nie do Kościoła, ale do „tego świata”, trzeba pozostawić Bogu (1 Kor 5,10). „Ten świat” św. Paweł kojarzy w 1 Kor 5,11 ze złem godzącym w samych jego sprawców („rozpustnicy”), przeciwko bliźnim („chciwcy i zdziercy”) i skierowanym przeciwko Bogu („bałwochwalcy”).

\subsubsection{Dwie reguły dotyczące tolerancji opisujące miejsce chrześcijan w świecie}

Św. Paweł rozróżnia dwa kręgi ludzi. Z jednej strony jest „ten świat w ogóle” (zob. 1 Kor 5,10: „nie chodzi o rozpustników tego świata w ogóle”), „ci, którzy są na zewnątrz” (domyślnie: Kościoła; 1 Kor 5,12), a z drugiej strony - „ci, którzy są wewnątrz" (1 Kor 5,12). Niejako na granicy tych dwóch zbiorowości są ci, którzy „nazywają się braćmi” (1 Kor 5,11), ale są ze wspólnoty wykluczeni, o czym była mowa wyżej.

W 1 Kor 5,12-13 należy dostrzec sekwencję: pytanie - pytanie (wiersz 12a i 12b), odpowiedź - odpowiedź (wiersz 13a i 13b), przy czym konieczne jest powiązanie wiersza $12 \mathrm{a} z$ wierszem $13 \mathrm{a}$ oraz wiersza $12 \mathrm{~b}$ z wierszem $13 \mathrm{~b}$ :

- Pytanie (w. 12a): „Jakże bowiem mogę sądzić tych, którzy są na zewnątrz?”

- Odpowiedź (w. 13a): „Tych, którzy są na zewnątrz, osądzi Bóg”.

- Pytanie (w. 12b): „Czy i wy nie sądzicie tych, którzy są wewnątrz?”

- Odpowiedź (w. 13b): „Usuńcie złego spośród was samych”.

6 Pwt 13,6; 17,7; 19,19; 22,24. 
Inaczej mówiąc: Czy mogę sądzić tych, którzy nie należą do Kościoła (por. wiersz 12a)? Nie! Osąd tych, którzy nie należą do Kościoła pozostawmy Bogu (por. wiersz 13a). Czy trzeba osądzać tych, którzy należą do Kościoła (por. wiersz 12b)? Tak, trzeba ich osądzać (por. wiersz 13b)! W ten sposób św. Paweł podaje zasadę nietolerancji wobec zła w Kościele i tolerancji wobec tych, którzy do Kościoła nie należą. Myślenie Apostoła jest w opozycji do podejścia sekciarskiego, bo nie zakłada zamknięcia się na świat zewnętrzny. Chrześcijanie powinni zachować kontakt ze światem (inaczej postępując, musieliby „całkowicie opuścić ten świat"; 1 Kor 5,10). W świecie, który zaczyna się tam, gdzie kończy się wspólnota (1 Kor 5,12), muszą oni tolerować zło, a jego osąd pozostawić Bogu. Ludzie nieprzyjmujący Ewangelii mają prawo do „inności”. Natomiast wewnątrz Kościoła obowiązuje dyscyplina, ponieważ Kościół zrzesza ludzi na zasadzie wolnego wyboru i nie może upodabniać się do świata, w którym żyje. Wymaganie dyscypliny, a więc nietolerancja wobec zła płynie jednak z miłości; ma na celu wstrząśnięcie błądzącymi i doprowadzenie do ich odwrócenia się od zła. Nawiązując do definicji tolerancji przyjętej we wstępie niniejszego artykułu, można powiedzieć, że św. Paweł domaga się od chrześcijan „zrzeczenia się"7 egzekwowania obiektywnej prawdy od nie-chrześcijan ${ }^{8}$ i, odwrotnie, przestrzegania zasad Ewangelii od współbraci. Oczywiście, polecenie tolerancji wobec nie-chrześcijan nie likwiduje nakazu misyjnego pozostawionego Kościołowi przez Jezusa. Nie jest zachętą do obojętności na los ludzi nieprzyjmujących Ewangelii, ale jest przypomnieniem, że do ich poglądów i postaw należy odnosić się z szacunkiem ${ }^{9}$.

7 Zob. A. Jougan, Słownik kościelny łacińsko-polski, s. 688: łacińskie słowo „tolerantia” oznacza „znoszenie, wytrwałość, cierpliwość, zrzeczenie się czegoś”.

8 „W świecie, który zaczyna się tam, gdzie kończy się Wspólnota (1 Kor 5,12), muszą oni tolerować zło i jego osąd pozostawić Bogu”; R. Völkl, Christ Und Welt,s. 268.

9 Św. Paweł głosił Ewangelię poganom z misjonarską miłością, której podstawy ukazuje w różnych etapach swojego życia: a) Bóg jest poznawalny w jakimś zakresie dla pogan: „Albowiem od stworzenia świata niewidzialne Jego przymioty - wiekuista Jego potęga oraz bóstwo - stają się widzialne dla umysłu przez Jego dzieła” (Rz $1,20)$; b) Treść Prawa jest wypisana w ich sercach; odczytują je w swych sumieniach (Rz 2,15); idąc za naturą, czynią to, co Prawo nakazuje (Rz 2,14); c) Chrystus jest wpisany w naturę każdego człowieka: On jest „pierworodnym wobec każdego stworzenia, bo w Nim zostało wszystko stworzone”; „wszystko w Nim ma istnienie” (Kol 1,15.17; por. Ef 2,10); d) Chrystus jest niejako wpisany w kosmos, który „aż dotąd jęczy i wzdycha w bólach rodzenia” (Rz 8,22) i „Z upragnieniem oczekuje objawienia się synów Bożych” $(\mathrm{Rz} 8,19)$. Relacja chrześcijan do Żydów różni się od relacji z „poganami” (tzn. nie-Żydami), o czym świadczy wykład zawarty w Rz 9-11. Połączenie Kościoła z Synagogą będzie wynikiem nadzwyczajnej interwencji Boga na końcu czasów. „I tak cały Izrael 


\subsection{Wnioski praktyczne z 1 Kor 5,1-13 związane z problemem tolerancji}

W życiu codziennym często stosowany jest, bezrefleksyjnie, schemat postępowania, który jest analogiczny z prawem „cheremu” opisanym w Starym Testamencie: model tolerancji wobec „swoich” i nietolerancji wobec „obcych”. Jest to sposób postępowania usprawiedliwiony wojną, dlatego jego konsekwencje można nazwać „etyką czasu wojny”, „etyką oblężonej twierdzy”. Jest to też etyka tych, którzy dążą do panowania nad innymi. Można go ukazać za pomocą następującego schematu:

$\begin{array}{ccc}\text { „ONI" } & \text { „MY” } & \text { „ONI” } \\ \text { NIETOLERANCJA } & \text { TOLERANCJA } & \text { NIETOLERANCJA } \\ \text { „ONI" } & \text { „MY” } & \text { „ONI” }\end{array}$

Wyjąwszy sytuację wojny, konieczne jest zastosowanie sposobu postępowania dokładnie odwrotnego:

$\begin{array}{ccc}\text { „ONI” } & \text { „MY” } & \text { „ONI” } \\ \text { TOLERANCJA } & \text { NIETOLERANCJA } & \text { TOLERANCJA } \\ \text { „ONI” } & \text { „MY” } & \text { „ONI” }\end{array}$

Św. Paweł domaga się od każdego chrześcijanina podjęcia trudu ciągłej konfrontacji z pokusą sekciarskiego patrzenia na świat. Chrześcijanie nie mają odcinać się od świata, ale mają prowadzić świat do zbawienia.

Troska o dobro tych, na których nam szczególnie zależy, których kochamy, którzy są nam bliscy ideowo, powinna owocować stawianiem im wymagań, nietolerancją wobec zła przez nich popełnianego. Dotyczy to także relacji w Kościele na linii: przełożony - podwładny. Równocześnie, należy uszanować „inność” tych, którzy są nam obcy ideowo.

Wydaje się, że w świecie mediów zbyt często chrześcijaństwo ma twarz surowych „prokuratorów”. Bierze się to stąd, że w dyskusjach światopoglądowych zaciera się rozróżnienie na „tych, co są wewnątrz” Kościoła i na tych, „co są na zewnątrz". Dyskusje na tematy światopoglądowe powinny uwzględniać w sposób jasny założenie, że wobec „tych, co są na zewnątrz” obowiązuje chrześcijan daleko posunięta tolerancja idąca w parze ze stawianiem wymagań wobec tych, którzy chcą utożsamiać się ze wspólnotą Kościoła, w której obowiązuje dyscyplina („wyższa sprawiedliwość”) oparta na Ewangelii.

będzie zbawiony” (Rz 11,26). „Cały Izrael” oznacza tu Kościół (Rz 9,8: „synowie obietnicy”) i Żydów, którzy nie uwierzyli w Ewangelię (Rz 9,8: „synowie co do ciała”). 
Model wskazany przez św. Pawła w Liście do Koryntian jest wiążący dla chrześcijan po dzień dzisiejszy, aczkolwiek domaga się uwzględnienia korekty, którą wprowadza sam św. Paweł w później napisanym Liście do Rzymian (por. Rz 14).

\section{Prymat miłości domaga się od „mocnych" stwarzania miejsca w Kościele dla „słabych” (Rz 14)}

1 Kor 5,1-13 nie jest ostatnim słowem św. Pawła na temat tolerancji i nietolerancji. Ostre wystąpienie przeciwko złu w Kościele, które znajduje się w 1 Kor 5,1-13, Apostoł uzupełnia w Rz 14 podaniem okoliczności, w których konieczna jest tolerancja wobec chrześcijan „słabych”.

\subsection{Teza wynikająca z Rz 14}

Z analizowanych wyżej tekstów źródłowych wynika, że tolerancja jest we wspólnocie Kościoła podporząakowana miłości (zob. 1 Kor 8-10), a granice tolerancji w Kościele są wyznaczane przez autorytet apostolski (zob. 1 Kor 5,1-13). W świetle tych dwóch zasad należy odczytać wskazania św. Pawła zapisane w Rz 14. Zakładając, że tolerancja w Kościele jest pochodną miłości, a jej granice wyznacza autorytet apostolski, pozostaje niemała sfera decyzji w życiu chrześcijanina, w której powinien on okazywać tolerancję wobec zła popełnianego przez współ-chrześcijan. Św. Paweł wymienia trzy okoliczności, w których zaleca postawę tolerancji (zob. Rz 14,15.19.22).

\subsection{Problemy wynikające $z$ błędnego rozumienia Ewangelii przez chrześcijan w Rzymie}

Tłem Rz 14 jest problem podobny do tego, który był powodem interwencji św. Pawła w 1 Kor 8-10, a mianowicie konflikt na tle rozumienia przepisów pokarmowych. Niektórzy chrześcijanie pochodzenia żydowskiego czy pogańskiego określeni jako „słabi w wierze” (Rz 14,1) uważali, że powinni po swoim nawróceniu zachowywać uprzednio przez siebie przestrzegane przepisy co do wstrzymywania się od pewnych pokarmów (zob. Rz 14,2-6). Kontrowersje dotyczyły także ustalania dni świętych (zob. Rz 14,5-6). Z punktu widzenia prawideł Ewangelii, nie mieli racji. Rozwiązanie konfliktu powstałego na tym tle wydawało się proste. Chrześcijanie trwający na gruncie prawdy Ewangelii wiedzieli, jak postępować, i uważali, że jedynym sposobem rozwiązania konfliktu we wspólnocie jest rewizja postępowania przez „słabych”. Niby mieli rację, ale co z tego, skoro efektem stereotypowej reakcji tych Koryntian był podział we 
wspólnocie. Św. Paweł znajduje rozwiązanie, które idzie na przekór stereotypom. Nie zadowala się przypomnieniem prawdy Ewangelii, na gruncie której stała jedna strona konfliktu i prostym dyscyplinowaniem „słabych”.

\subsection{Korekta postawy Rzymian dokonana przez św. Pawła}

$\mathrm{Na} \mathrm{Rz} 14$ należy spojrzeć w świetle generalnej zasady zapisanej w Rz 12,1-2, według której chrześcijanie powinni kierować się rozumem w przekładaniu principiów ewangelicznych na szczegółowe decyzje moralne. Do tej sprawy powrócimy w zakończeniu niniejszego artykułu.

Zalecenia św. Pawła idą w dwóch kierunkach, wyartykułowanych w dwóch częściach perykopy: w Rz 14,1-13a i w Rz 14,13b-23.

\subsection{1. „Przestańmy wyrokować jedni o drugich” (Rz 14,13a; por Rz 14,1-13a)}

W skrajnych wierszach pierwszej części perykopy znajdują się polecenia stanowiące główną myśl tej części wywodu św. Pawła: najlepiej, gdyby wszyscy okazali tolerancję i „bez spierania się o poglądy” (Rz 14,1) zastosowali zasadę: „Przestańmy wyrokować jedni o drugich” (14,1-13a). Zadanie to dotyczy obu stron konfliktu, co podkreśla paralelizm zwrotów: „Jeden... drugi...” (Rz 14,2.5); „ten, kto jada... ten, który nie jada...” (Rz 14,3). Św. Paweł zaleca wszystkim następującą postawę:

- niech [nikt nikim] nie pogardza..., [nikogo] nie potępia

- niech każdy trzyma się swego przekonania

- przestańmy więc wyrokować jedni o drugich.

Każdy, kto postępuje zgodnie ze swoimi przekonaniami, chwali Pana i składa dzięki Bogu (Rz 14,5-6). Osąd należy pozostawić Bogu (Rz 14,10-12).

\subsection{2. „A raczej to zawyrokujcie, by nie dawać bratu sposobności do upadku} lub zgorszenia" (Rz 13,13b; por. Rz 14,3b-23)

Począwszy od Rz 14,13b św. Paweł podaje wskazówki potrzebne na wypadek, gdyby niemożliwe było załagodzenie konfliktu przez obie strony. Od pierwszego zdania czternastego rozdziału Listu do Rzymian wiadomo, że tylko jedna strona konfliktu miała rację. Św. Paweł zaświadcza to uroczystym odwołaniem się do autorytetu: „Wiem i jestem przekonany w Panu Jezusie, że...” (Rz 14,14). Rozwiązanie sytuacji widzi w postawieniu wymagań właśnie tej grupie, po stronie której stała obiektywna racja. Podobnie jak w 1 Kor 8-10, także w Rz 14 św. Paweł wprowadza mechanizm rozwiązywania konfliktów, którym jest tolerancja. Zaleca „mocnym” samoograniczenie. Zamiast wyrokować jedni o drugich, 
mają tak postępować, „by nie dawać sposobności do upadku lub zgorszenia” (Rz 14,1). W jaki sposób? W Rz 14,13b-23 przeplatają się: wykład i aplikacja, przy czym aplikacje zawierają trzy reguły, którymi powinni kierować się „mocni” wobec „słabych”. Reguły te wskazują na to, w jakich okolicznościach wskazane jest okazanie „słabym” tolerancji („zrzeczenia się” egzekwowania prawdy, zgodnie z definicją tolerancji podanej przez nas we wstępie artykułu):

a) Rz 14,14 (wykład). Św. Paweł oddziela płaszczyznę obiektywnej prawdy od płaszczyzny przekonań, gdy stwierdza, że nie ma rzeczy nieczystych, a są one nieczyste tylko dla tego, kto je uważa za nieczyste.

b) Rz 14,15-16 (aplikacja). Ten, kto stoi na gruncie prawdy powinien zrezygnować z jej demonstrowania, jeśli postępowaniem swym zasmuca swego brata. W przeciwnym przypadku nie działa zgodnie z miłością i czyni z zasady chrześcijańskiej wolności okazję do grzechu (groźby posądzenia o bluźnierstwo przez brata trwającego w błędzie). W ten sposób św. Paweł podaje zasadę o kapitalnym znaczeniu dla życia Kościoła: wolność chrześcijańska ma granice, które wyznacza miłość bliźniego. Gdy ktoś, kto kieruje się obiektywną prawdą zauważy, że stawia swego brata w sytuacji, która go zasmuca, powinien zaniechać demonstrowania swej wolności. Św. Paweł nie podpowiada, czy postawa tolerancji obowiązuje w tym przypadku „zawsze i wszędzie”, czy też w tylko w pewnych okolicznościach. Kwestię tę reguluje w Rz 12,1-2 (tekst ten omówimy niżej).

c) Rz 14,17-18 (wykład). „Królestwo Boże to nie sprawa tego, co się je i pije, ale to sprawiedliwość, pokój i radość w Duchu Świętym” (Rz 14,17). Taki sposób służby Chrystusowi podoba się Bogu i przynosi uznanie u ludzi (Rz 14,18).

d) Rz 14,19-21 (aplikacja). „Starajmy się więc o to, co służy sprawie pokoju i wzajemnemu zbudowaniu. Nie burz dzieła Bożego ze względu na pokarmy” (Rz 14,19-20a). W ten sposób św. Paweł podaje drugą zasadę porządkującą życie wspólnoty Kościoła: autentyzm wolności chrześcijańskiej poznaje się po tym, że jej owocem jest pokój i zbudowanie wspólnoty (znakiem dyskwalifikującym jest „burzenie”). Taki jest drugi powód, dla którego należy rezygnować $\mathrm{z}$ demonstrowania racji wobec „słabych w wierze".

e) Rz 14,22-23. „Mocni” mogą zawiesić zasadę kierowania się silnym przekonaniem („wiarą”; słowo „pistis” powtarza się tu trzykrotnie), wybierając czasem „liberalizm wobec chrześcijan, zachowujących w dobrej wierze te praktyki” ${ }^{10}$. Św. Paweł poleca zachowanie własnego przekonania „dla siebie przed Bogiem” (Rz 14,22).

10 Komentarz BT dot. Rz 14,1. 


\subsection{Wnioski praktyczne z Rz 14 związane z problemem tolerancji}

Zalecenia św. Pawła zawarte w Rz 14 nie przekreślają generalnej zasady opisanej w 1 Kor 5,1-13, z której wynika, że - w imię miłości - w gronie osób sobie bliskich należy stawiać sobie wzajemnie wymagania. Zasady tej nie należy rozumieć w sposób bezwzględny. Sztywne stosowanie tej zasady np. w życiu rodzinnym czyniłoby życie nieznośnym. Potrzebne jest pozostawianie innym marginesu na błędy. Kierując się miłością, znajduje się odpowiedzi na pytanie, kiedy, i w jakich okolicznościach, należy „przymknąć oczy” na słabości innych, nie rezygnując równocześnie $\mathrm{z}$ obrony spraw pryncypialnych. Warto $\mathrm{w}$ swoich decyzjach uwzględnić rady św. Pawła zapisane w Rz 14 i pytać siebie: Czy warto, w konkretnej sytuacji, w odniesieniu do konkretnych ludzi, egzekwując jakieś reguły, zasmucać bliźniego (por. Rz 14,15)? Czy warto rozbijać wspólnotę z nim (por. Rz 14,19)? Czy nie lepiej czasem zamilknąć, gdy bliźni popełnia błąd, a nie jest tego świadomy (por. Rz 14,22-23)?

Zalecenia św. Pawła zawarte w Rz 14 powinny skłaniać do refleksji nad koniecznością pluralizmu w Kościele ${ }^{11}$.

List do Rzymian jest dokumentem konstytutywnym kręgu kultury euro-atlantyckiej ${ }^{12}$, dlatego zalecenia św. Pawła na temat tolerancji powinny być traktowane jako głos w dyskusji nad tożsamością Europy. Wydaje się, że w kręgu polityków decydujących o przyszłości Europy dominuje tendencja do absolutyzowania tolerancji, co prowadzi Europę do utraty własnej tożsamości. Tymczasem, jak zaznaczyliśmy we wstępie artykułu, „tolerancja nie oznacza całkowitego czy nawet częściowego wyrzeczenia się własnych przekonań. Tolerancja nie wymaga pomniejszania czy uszczuplenia w czymkolwiek orędzia Ewangelii, wzywa jedynie do dialogu"13.

11 Od zarania chrześcijaństwa istniały w jednym Kościele różnice w sposobach przeżywania wiary. Wrażliwość wiary św. Jana, widoczna w Czwartej Ewangelii, w Listach św. Jana i - w sensie peryferyjnym - w Apokalipsie św. Jana, posiada swą specyfikę w stosunku do wrażliwości wiary św. Pawła, którą możemy poznać z trzynastu kanonicznych listów św. Pawła. Własne piętno na wspólnotach odcisnęli też: św. Jakub, św. Juda i św. Piotr, czego świadectwem są ich listy apostolskie.

12 Zob. P. Rossano, La lettera ai, s. 31-47.

13 A. Grabner-Haider, Tolerancja, s. 1321. 


\section{Zakończenie}

We wstępie artykułu podaliśmy określenie tolerancji, które było podstawą wyodrębnienia tekstów źródłowych traktujących o tolerancji w Listach św. Pawła. W toku analizy tekstów źródłowych postawiliśmy trzy tezy dotyczące problematyki tolerancji i dowiedliśmy, że:

1. Tolerancja jest funkcją miłości. Jako taka, nie jest wartością „samą w sobie", autonomiczną (1 Kor 8-10).

2. Chrześcijanie powinni być tolerancyjni wobec „tych, którzy są na zewnątrz [Kościoła]”. Powinni być nietolerancyjni wobec zła popełnianego przez „tych, którzy są wewnątrz [Kościoła]”, w granicach wyznaczonych przez autorytet apostolski (1 Kor 5,3-11).

3. Zakładając, że tolerancja w Kościele jest pochodną miłości, a jej granice wyznacza autorytet apostolski, pozostaje niemała sfera decyzji w życiu chrześcijanina, w której powinien on okazywać tolerancję wobec błędów popełnianych przez współ-chrześcijan. Św. Paweł wymienia trzy okoliczności, w których zaleca postawę tolerancji (zob. Rz 14,15.19.22).

Reguły „ewangelii o tolerancji”, które znajdujemy w Listach św. Pawła domagają się uzupełnienia o odpowiedź na pytanie, w jaki sposób chrześcijanie mogą "przekładać” Ewangelię na realia życiowe. Odpowiedź na to pytanie znajduje się w dwóch tekstach św. Pawła: w Rz 12,1-2 i w 1 Kor 6,1-11. Tekst zawarty w Rz 12,1-2 wiąże się z problematyką tolerancji opisaną w Rz 14, gdyż zawiera „złotą regułę”, w świetle której chrześcijanin powinien odnajdywać się w różnych obszarach życia opisanych w Rz 12,2-15,13 ${ }^{14}$. Z kolei, w 1 Kor

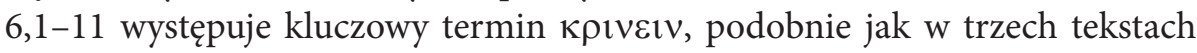
źródłowych analizowanych w niniejszym artykule.

Aby uchwycić specyfikę praktycznych rad św. Pawła zawartych w Rz 12,1-2 i w 1 Kor 6,1-11, trzeba zauważyć, że droga od zasad dotyczących tolerancji do ich realizacji w konkretnych realiach życiowych może być opisana na dwa sposoby. Jedną z nich ilustruje Talmud. W tradycji rabinistycznej, która zaowocowała powstaniem komentarza do Tory w postaci dwóch Talmudów (zwanych Torą ustną), znajduje się 613 zakazów i nakazów, które stanowią rodzaj szczegółowego przewodnika postępowania w konkretnych sytuacjach życiowych. Jako przykład można podać tekst z Miszna Szabbat 7,2 będący komentarzem do przykazania biblijnego: „Pamiętaj, aby dzień święty święcić”(zob. Wj 20,8-11). Co oznacza według tradycji talmudycznej „święcenie szabatu”? Czytamy: „Jest 39 kategorii prac zakazanych w szabat: 1. siać, 2. orać, 3. żąć, 4. wiązać snopki,

14 Zob. G. Rafiński, Rozum jako źródło, s. 335-357. 
5. młócić, [...], 34. budować, 35. burzyć, 36. gasić płomień, 37. zapalić płomień, 38. uderzać młotkiem, 39. przenosić się z jednego ogrodzenia do drugiego"15. Jest to droga tych, którzy w każdej szczegółowej sytuacji będą szukali gotowej odpowiedzi spisanej bądź przekazanej ustnie przez jakiś zewnętrzny autorytet.

Św. Paweł wybiera inną drogę, wskazując na dwie „instancje” decydujące w życiu chrześcijanina o dopuszczalności decyzji dyktowanych tolerancją (i nietolerancją). Instancją zasadniczą, do której powinien odnieść się chrześcijanin, jest jego własny rozum (zob. Rz 12,1-2). Drugim kryterium jest opieranie decyzji na Ewangelii, która zawiera reguły „wyższej sprawiedliwości” w stosunku do sprawiedliwości ludzi „tego świata” (zob. 1 Kor 6,1-11).

W Rz 12,1-2 czytamy: „A zatem proszę was, bracia, przez miłosierdzie Boże, abyście dali siebie na ofiarę żywą, świętą, Bogu przyjemną, jako wyraz waszej rozumnej służby Bożej. Nie bierzcie wzoru z tego świata, lecz przemieniajcie się przez odnawianie umysłu, abyście umieli rozpoznać, jaka jest wola Boża: co jest dobre, co Bogu przyjemne i co doskonałe".

W tekście tym znajduje się trzykrotne odniesienie do rozumu, do trudu intelektualnego. Jest w nim mowa o „rozumnym kulcie” ( $\lambda$ o $\gamma ı \kappa \lambda \alpha \tau \rho \varepsilon 1 \alpha)$, o „odnawianiu umysłu” i o „rozpoznawaniu, jaka jest wola Boża”. Rozum jest podstawową „instancją”, do której powinien odnosić się chrześcijanin w swych decyzjach. Oczywiście, jak wiemy z Rz 2, nie chodzi o rozum "naturalny”, bo ten ma ogląd rzeczywistości zaciemniony przez grzech, ale chodzi o umysł wsparty mocą Ducha Świętego (zob. kontekst dalszy w postaci Rz 8).

Życie ludzkie, widziane z perspektywy konkretnych uwarunkowań (tak trzeba rozumieć pojęcie ciała, $\sigma \omega \mu \alpha)$, jest ofiarą składaną Bogu, którą św. Paweł porównuje do ofiar składanych w świątyni jerozolimskiej (ofiary ze zwierząt były „żywe, święte, Bogu przyjemne”). Życie ludzkie jest kultem daleko wspanialszym przez fakt rozumności. Rozumne decyzje podejmowane przez chrześcijanina sprawiają, że nabiera ono charakteru sakralnego. Nie ma sensu podział życia chrześcijańskiego na czas „sacrum” i czas „profanum”, bo także życie codzienne jest kultem ofiarowywanym Bogu. W Rz 12,2 św. Paweł pre-

15 J. J. Petuchowski, La Voce del Sinai, s. 67-68: Vi sono trentanove categorie principali di lavoro proibito il sabato: 1 . seminare, 2. arare, 3. mietere, 4. legare cavoni, 5. trabbiare, 6. spulare, 7. pulire frutta, 8 . macinare, 9 . setacciare, 10 . impastare, 11 . cucinare, 12 . tosare la lana, 13. lavare lana, 14. battere lana, 15. tingere lana, 16. filare, 17. ordire, 18. fare due staffe, 19. tessere due fili, 20. dividere due fili, 21. fare un nodo, 22. sciogliere un nodo, 23. cucire due punti, 24. stracciare per cucire due punti, 25. prendere un capriolo, 26. scannare un capriolo, 27. lavare la pelle a un capriolo, 28. salarla, 29. lavarla, 30. raschiarne i pelli, 31. tagliare il capriolo, 32. scrivere due lettere, 33. cancellare per scrivere due lettere, 34 . costruire, 35. demolire, 36. spegnere il fuoco, 37. accendere il fuoco, 38. battere il martello, 39. trasportare da un recinto all'altro. Mishnah Shabbath 7,2. 
cyzuje, co rozumie przez „rozumny kult”, podając dwie zasady pomocnicze. Zasada negatywna brzmi: „nie bierzcie wzoru z tego świata”. Zasada pozytywna stanowi: „przemieniajcie się przez odnawianie umysłu”. Św. Paweł dodaje dalej wyjaśnienie, na czym ma polegać „przemienianie się przez odnawianie umysłu”. Chodzi o trud intelektualny, który ma na celu rozpoznawanie tego, „jaka jest wola Boża”. Wolą Bożą zaś jest to, aby chrześcijanie wybierali w swych decyzjach to, „co jest dobre, co Bogu przyjemne i co doskonałe”.

Warto zauważyć, jak wielkie jest zaufanie św. Pawła do człowieka. Nie podważa go nawet to, że przy podejmowaniu rozumnych decyzji człowiek może popełniać błędy. Rozumne decyzje chrześcijanina są bowiem „zanurzone” w Bożym miłosierdziu, czemu św. Paweł daje wyraz w pierwszych słowach „złotej reguły” zawartej w Rz 12,1-2: „A zatem proszę was, bracia, przez miłosierdzie Boże..." (Rz 12,1).

W 1 Kor 6,1-11 znajduje się druga fundamentalna rada św. Pawła na temat stosowalności tolerancji. Wyznacznikiem decyzji chrześcijanina musi być „wyższa sprawiedliwość”, a nie mądrość tego świata. Rada ta została sformułowana w kontekście historycznym odległym od naszych realiów, co nie przekreśla jej aktualności. W sytuacjach konfliktowych niektórzy Koryntianie szukali arbitrażu przed sądami trybunału „polis”. Św. Paweł ocenia to jako „wstyd” (1 Kor 6,5). Dlaczego? Bo postawa chrześcijan powinna odpowiadać „wyższej sprawiedliwości” opartej na Ewangelii. Wymagania Ewangelii zaś są takie, że bracia w ogóle nie powinni się spierać, a w przypadku krzywdy powinna obowiązywać zasada: „Czemuż nie znosicie niesprawiedliwości? Czemuż nie ponosicie raczej szkody" (1 Kor 6,7). Postawa tolerancji obowiązująca tych, którzy doświadczają (niesłusznych?) oskarżeń jest niekoniecznie zrozumiała dla ludzi „tego świata”. Chrześcijańskie pojmowanie tolerancji posiada swoją specyfikę przez odniesienie do fundamentu, jakim jest Ewangelia.

\section{Bibliografia}

Fee G.G., The First Epistle to the Corinthians, Grand Rapids1973.

Grabner-Haider A., Tolerancja, w: Praktyczny Słownik Biblijny, Opracowanie zbiorowe katolickich i protestanckich teologów, A. Grabner-Haider (red.), T. Mieszkowski, P. Pachciarek (przekład i opracowanie), Warszawa 1995 (oryginał: Freiburg im Breisgau 1969), s. 1320-1321.

Jougan A., Słownik kościelny łacińsko-polski, Warszawa 1992.

Pesce M., Le due fasi della predicazione di Paolo. Dall'evangelizzazione alla guida della comunità, Bologna 1994.

Petuchowski J. J., La Voce del Sinai. Letture rabbiniche sui Dieci Comandamenti dagli scritti ebraici e aramaici, Napoli1985. 
Rad von G., Teologia Starego Testamentu, Warszawa 1986.

Rafiński G., Z problematyki genezy pism z Qumran (w 40. rocznice pierwszych odkryć), Ruch Biblijny i Liturgiczny 40 (1987), s. 465-476.

Rafiński G., Rozum jako źródło wartości moralnej czynu ludzkiego w Liście św. Pawła do Rzymian, w: Miłość jest z Boga. Wokół zagadnień biblijno-moralnych. Studium ofiarowane ks. prof. dr. hab. Janowi Łachowi, M. Wojciechowski (red.), Warszawa 1997, s. 335-357.

Rossano P., La lettera ai Romani e il suo influsso sulla cultura europea, w: P. Rossano, R. Penna, U. Vanni, A. Rigobello, E. Bianchi, R. Di Segni, Attualità della lettera ai Romani, Roma 1989, s. 31-47.

Völkl R., Christ Und Welt nach dem Neuen Testament, Würzburg 1961. 